STUDIA HISTORICA GEDANENSIA

TOM VIII (2017)

\begin{abstract}
Andrzej Topij
(Instytut Historii i Stosunków Międzynarodowych, Uniwersytet Kazimierza Wielkiego, Bydgoszcz)

\section{Polityka narodowościowa Łotwy w okresie rządów autorytarnych Kārlisa Ulmanisa (1934-1940)}

Łotwa była jednym z najbardziej zróżnicowanych pod względem narodowym krajów w Europie międzywojennej. Mimo niewielkiego obszaru zamieszkiwało ją, obok narodu nominalnego - Łotyszów, aż osiem narodów: Niemcy, Rosjanie, Polacy, Żydzi, Białorusini, Litwini, Estończycy i Liwowie. Co więcej, stanowili oni łącznie wysoki odsetek ogółu ludności: 26,50\% w 1925 r. i 25\% w 1935 r. Największą mniejszością narodową byli Rosjanie (123 336 - 11,97\%), na drugim miejscu plasowali się Żydzi (93 479 - 4,79\%), a na trzecim - Niemcy (62 144 - 4,97\%). Ludność polska w 1935 r. liczyła 48949 osób, co stanowiło 3,19\% Trzeba jednak zaznaczyć, że są to dane oficjalne, często kwestionowane przez przedstawicieli samych mniejszości lub innych współczesnych badaczy, również polskich. Niewątpliwie dużo do myślenia daje fakt, że według spisu powszechnego z roku 1930 Polaków było 59 374, a pięć lat później aż prawie o 11000 mniej - i to zważywszy na fakt, iż dzietność rodzin polskich była wtedy wysoka.

Większa część tej ludności zamieszkiwała w miastach; w szczególności dotyczyło to Niemców i Żydów. Ryga odznacza się tak wysoką liczbą nie-Łotyszy nie tylko w czasach współczesnych czy radzieckich. Dotyczy to też okresu międzywojennego, choć wówczas te proporcje nie były aż tak niekorzystne dla Łotyszy. Bądź co bądź, stanowili oni większość w stolicy swojego kraju. W 1935 r. w Rydze było prawie $64 \%$ Łotyszów ${ }^{2}$.

Mniejszości narodowe, choć w bardzo nierównej mierze, zajmowały silną pozycję w życiu gospodarczym i intelektualnym Łotwy. W największym stopniu dotyczyło to Niemców i Żydów. Jeszcze w 1930 r., a więc 12 lat po uzyskaniu

$1 \quad$ Latvijas skaitlos 1935 (Rīga: Valsts Statistika Parvalde, 1936), 39; Zur Bevölkerungsstatistik Lettlands und insbesonderedes Deutschtums in Lettland, Jahrbuch des baltischen Deutchtums in Lettland 1926, 51.

2 Latvijas skaițos, 53. 
niepodległości, w grupie inteligenckiej Łotysze stanowili 53,6\%, Niemcy - 18,9\%, Żydzi - 13,1\%, Rosjanie - 9,1\%, Polacy - 2,6\%, Litwini - 0,7\%, a Estończycy 0,4\% ${ }^{3}$. Jeszcze słabsza była pozycja Łotyszy w życiu gospodarczym, zwłaszcza w przemyśle i handlu. I tak np. zaledwie 25\% kapitału towarzystw akcyjnych znajdowało się w rękach łotewskich, gdy tymczasem Żydzi byli właścicielami 36\%, zaś Niemcy $35 \%$ kapitału tych towarzystw ${ }^{4}$. Nie trzeba dodawać, że w handlu i bankowości również zaznaczała się silna pozycja Żydów i Niemców. Do połowy lat trzydziestych banki łotewskie były stosunkowo nieliczne i słabe, a niektóre z nich miały charakter wyłącznie spekulacyjny i ich kapitał istniał tylko na papierze ${ }^{5}$. Jednak korzystnie przedstawiała się dla Łotyszy sytuacja w rolnictwie, a to dzięki przeprowadzeniu po pierwszej wojnie światowej bardzo radykalnej reformy rolnej, która całkowicie zlikwidowała niemiecką, a w Łatgalii polską, własność obszarniczą ${ }^{6}$.

W pierwszym okresie, do przewrotu Kārlisa Ulmanisa w 1934 r., Łotwa była republiką parlamentarno-demokratyczną, z wyraźnie dominującą pozycją sejmu nazywanego tu Saeimą. Niewątpliwie musiało to też zaważyć na przyjętych wtedy rozwiązaniach odnoszących się do pozycji mniejszości narodowych. Proponowany artykuł 116 konstytucji, który przewidywał zakładanie stowarzyszeń mających osobowość prawną przez mniejszości narodowe, został wprawdzie odrzucony, ale ustawa szkolna z 1919 r. dała mocną podstawę do stworzenia szkolnictwa mniejszości narodowych, w stosunkowo niewielkim stopniu podporządkowanego Ministerstwu Oświaty. Z tego rozwiązania najpełniej skorzystali Niemcy bałtyccy ${ }^{7}$.

Wszystko to naturalnie musiało spowodować narastające nastroje antymniejszościowe wśród części społeczeństwa łotewskiego, z czasem wyrażające się popularnym hasłem „Łotwa dla Łotyszy”. Pogłębił to jeszcze wielki kryzys z początku lat trzydziestych. Za kursem nacjonalistycznym zaczęli się teraz wprost opowiadać niektórzy politycy dotychczasowego establishmentu politycznego, w pierwszej kolejności Margers Skujenieks, który w grudniu 1931 r. stanął na czele rządu, inicjując nowy kurs w polityce narodowościowej. Wyraziło się to przede wszystkim w dziedzinie szkolnictwa. Minister oświaty Atis K̦ēniņš rozpoczął walkę o jedyną (tj. naturalnie łotewską) kulturę na Łotwie (Niemcy bałtyccy nazwali ją nawet, zresztą na wyrost, „Kulturkampfem”). W praktyce znalazło to swoje

3 I. Baumerts, G. Kurlovits, A. Tomasuns, Osnownyje woprosy istorii Latwii (Riga, 2002), 11.

4 Ireneusz T. Kolendo, Łotwa. Zarys dziejów narodu i państwa. Od czasów najdawniejszych do początku XXI w. (Łódź: Księży Młyn. Dom Wydawniczy Michał Koliński, 2014), 167.

5 Andrzej Topij, Mniejszość niemiecka na Łotwie i w Estonii 1918-1939/41 (Bydgoszcz: Wydawnictwo Wyższej Szkoły Pedagogicznej, 1998), 78-81.

6 Piotr Łossowski, Kraje battyckie na drodze od demokracji parlamentarnej do dyktatury (1818-1934) (Wrocław: Zakład Narodowy im. Ossolińskich, 1972), 37-39.

7 Michael Garleff, „Die kulturelle Selbstverwaltung der nationalen Minderheiten in den baltischen Staaten”, w Die deutsche Nationen: Estland, Lettland, Lituanen, Band 4 (Köln: 1991), 92; Wolfgang Wachtsmuth, „Von deutscher Schulpolitik und Schularbeit im baltuschen Raum von ihren Anfängen bis 1939”, Deutsches Archiv für Landes- und Volksforschung, Band 7(12) (1943): 45-89. 
odzwierciedlenie w próbach ograniczenia autonomii szkolnej mniejszości narodowych. Swoje działania minister uzasadniał tym, iż położenie szkół mniejszości narodowych jest lepsze niż łotewskich. Zasadniczych zmian nie udało mu się zresztą osiągnąć, a rząd Skujenieksa upadł w czerwcu $1933 \mathrm{r}^{8}$

Groźniejsza mogła się wydawać hałaśliwa kampania wyraźnie faszyzującego nacjonalistycznego ugrupowania łotewskiego, występującego najpierw pod nazwą Ugunskrusts, a później Perkonkrust ${ }^{9}$, której przywódcą był Gustavs Celmiņš. Jako naczelne hasło Perkonkrust wysunął postulat „Łotwy dla Łotyszy”, a w swojej propagandzie faktycznie rozpalał nienawiść do mniejszości narodowych, głównie tych najwięcej znaczących, czyli Niemców i Żydów. Idąc wzorem narodowych socjalistów próbował m.in. urządzać bojkoty gospodarcze Żydów, a nawet wywołać pogrom, jak np. latem 1933 r. w Krasławiu nad Dźwiną ${ }^{10}$.

Perkonkrustowi nie dane jednak było święcić tryumfów nazistów czy choćby zresztą sąsiednich wabsów w Estonii ${ }^{11}$. Zaważył na tym przed wszystkim rozwój sytuacji na Łotwie, gdzie w nocy z 15 na 16 maja 1934 r. dokonano przewrotu państwowego - przewrotu, rzec można, bardzo specyficznego, gdyż zamachowcem na dotychczasowy ustrój państwa okazał się aktualnie urzędujący premier, Ulmanis. Nic dziwnego, że wydarzenie to przebiegło bardzo sprawnie i bezkrwawo ${ }^{12}$. Data 15 maja 1934 r. okazać się miała wyraźną cezurą w dziejach Łotwy w okresie międzywojennym. Nastał czas rządów autorytarnych, co prawda bez krwawych represji, ale na pewno niemający nic wspólnego z zasadami demokratycznymi. Ulmanis rządził faktycznie po dyktatorsku, bez żadnego parlamentu (co było ewenementem nawet w ówczesnej Europie), bez partii (wszystkie, łącznie z jego Związkiem Chłopskim, zostały rozwiązane). Ulmanis ogłosił się oficjalnie vadonisem (czyli wodzem), a w $1936 \mathrm{r}$. mianował sam siebie prezydentem Łotwy ${ }^{13}$.

$\mathrm{Z}$ niezwykłą energią premier-prezydent-vadonis przystąpił do przebudowy politycznej i gospodarczej państwa, osiągając znaczne sukcesy. Podobnie było w dziedzinie kultury i oświaty. Dość powiedzieć, że na Łotwie w połowie lat trzydziestych na 10000 mieszkańców przypadało 30,4 studentów, co plasowało to państwo na pierwszym miejscu w Europie (dla porównania: we Francji tylko 20,8, w Wielkiej Brytanii - 11,5, a w Niemczech - 10,2) ${ }^{14}$. Nic dziwnego, że Ulmanis okazał się bardzo popularnym dyktatorem ${ }^{15}$.

\footnotetext{
$8 \quad$ Istorija Latviji. XX wiek (Rīga: Jumava, 2005), 213.

9 Ugunkrusts - w wolnym tłumaczeniu - krzyż ognisty; Perkonkrust - krzyż błyskawica.

10 Łossowski, Kraje baltyckie, 202-203.

11 Wabsowie - potoczna nazwa członków organizacji: Estoński Związek Uczestników Wojny Wyzwoleńczej (est. Eesti Vabadussõjalaste Liit, EVL), działającej w latach trzydziestych wieku XX.

12 Szerzej o samym przebiegu przewrotu: V. Lācis, Latviešu zemes un tautas vēsture (Rīga, 2006), 313-314.

13 Więcej o samym Ulmanisie: Kārlim Ulmanim (Rīga: LN izdevnieciba, 2012).

14 Ibidem, 296.

15 O Ulmanisie i jego działalności po 1934: Kārlim Ulmanim, 48-60.
} 
Jak łatwo się domyślić, Ulmanis, zresztą zgodnie z duchem czasu, prowadził politykę nacjonalistyczną, siłą rzeczy uderzającą w mniejszości narodowe, choć trzeba wyraźnie zaznaczyć, że nie była to jednak polityka represji i ucisku narodowego. W oficjalnej ideologii kult państwa zajmował poczesne miejsce. Państwo miało być syntezą narodu, ojczyzny i samego reżymu. Wyrażano pogląd, że w przyszłości pojęcie państwa i narodu stanie się identyczne ${ }^{16}$. Naturalnie takie zapowiedzi nie wróżyły nic dobrego dla mniejszości narodowych. Na wykładzie dla nauczycieli historii 13 sierpnia 1934 r. Ulmanis podał nawet oficjalną definicję narodu jako świadomości wspólnej krwi, honoru, obyczajów i historii ${ }^{17}$. Na innym wykładzie, tym razem na konferencji historyków krajów bałtyckich w Rydze 16 sierpnia 1937 r., zdefiniował naród jako syntezę masy i polityki, określając go mianem siły napędowej historii1" ${ }^{18}$. Te myśli wodza następnie powtarzano, ale też $\mathrm{i}$ „twórczo” rozwijano w wielu pracach, jak np. w książce Ernesta Brastiņša pt. Doktryna narodowości $1^{19}$.

Dążąc do zapewnienia narodowi państwowemu decydującej roli podejmowano kroki służące specjalnie i bezpośrednio jego wzmocnieniu i konsolidacji. Na pierwszym miejscu znalazła się tu akcja „unaradawiania” imion własnych, a zwłaszcza nazwisk. W związku z tym powołano specjalną komisję, której zadaniem było sporządzenie wykazu imion łotewskich. Komisja miała w 1936 r. wydać kalendarz zawierający pełny spis takich imion. Wszakże z braku około stu łotewskich odpowiedników będących w użytku imion publikacji nie zdążono w terminie przygotować. Nasilenie akcji „,unaradawiania” imion i nazwisk przypadło dopiero na 1939/40 $\mathrm{r}^{20}$

W porównaniu z pozostałymi krajami bałtyckimi na Łotwie polityka umacniania pozycji narodu nominalnego oznaczała przede wszystkim możliwie jak najszersze wyrugowanie mniejszości z życia gospodarczego i ograniczenie ich praw w dziedzinie szkolnictwa. Należy też pamiętać, iż zmiana samego systemu politycznego musiała uderzyć w życie publiczne także mniejszości narodowych. Zniknęły ich partie, a pozostałe organizacje były poważnie skrępowane w swojej działalności z racji utrzymywanego do lutego 1938 r. stanu wojennego. Na każde posiedzenie jakiejkolwiek komisji, organizacji, zarządu trzeba było uzyskać pozwolenie. Z kolei już po zniesieniu stanu wojennego wszystkie bez wyjątku związki i organizacje (w tym naturalnie i łotewskie) musiały zarejestrować się od nowa ${ }^{21}$.

W pierwszej kolejności postanowiono wyrugować mniejszości z aparatu państwowego, tam gdzie się jeszcze zachowali ich przedstawiciele. Dotyczyło to głównie wymiaru sprawiedliwości. Rozpoczęło się systematyczne zwalnianie sędziów i prokuratorów. Przedstawicielom mniejszości narodowych zagrodzono

16 R. Bērziṇs-Valdess, Vienības èka, w Latvija 20 gados neatkariba 1918-1938 (Rìga, 1938), 269-270.

17 Rigasche Rundschau 14 VIII 1934.

18 Kārlis Ulmanis, Uzvaras cel̦š. Rakstu unrunu izlase un izvilkumi (Rīga, 1939), 184.

19 Ernest Brastinšs, Tautības mācība (Rīga: Zemnieka Domas, 1935), 23.

20 Łossowski, Kraje battyckie, 269.

21 Latvijas Valsts vēstures archīvs, Ryga, fonds 5921, apraksts 1, lieta 8, s. 7. 
też dostęp do prokuratury. Nadzorował tę akcję bezpośrednio Hermanis Apsits, który oświadczył: „Honor narodowy wymaga, aby również w sądach Łotysze byli panami swego kraju"22.

Biorąc pod uwagę fakt silnej pozycji Niemców bałtyckich oraz starą wrogość Łotyszy do Niemców i wszystkiego, co z nimi związane, nie dziwi, że główne uderzenie zostało skierowane właśnie przeciw tej mniejszości. Zaraz po przewrocie 15 maja 1934 r. ogłoszono manifest o usunięciu wszystkich obcych zjawisk z życia publicznego Łotwy. W związku z tym władze zaczęły wymazywać niemieckie, ale też i wszelkie inne obce ślady z historii Łotwy. Jako klasyczny przykład tej polityki należy wymienić usunięcie $\mathrm{z}$ ratusza portretów dwóch wybitnych burmistrzów Rygi, Ludwiga W. Kerkoviusa i Georga Armitsteada ${ }^{23}$.

W walce z wpływami mniejszości narodowych, a zwłaszcza Niemców bałtyckich, w życiu publicznym Łotwy bardzo pomocny był Urząd Informacji i Propagandy, którym kierował Alfred Bērzins, jeden z najbliższych współpracowników Ulmanisa. To właśnie on przygotował opinię publiczną do nowych kroków podejmowanych przez rząd łotewski wobec mniejszości niemieckiej. Publikował serię artykułów jako Nordicus (nie było jednak wówczas powszechnie wiadomo, kto krył się za tym pseudonimem) w największej gazecie łotewskiej, „Jaunākās Ziņas”. Przede wszystkim kwestionował lojalność mniejszości niemieckiej wobec państwa łotewskiego i próbował wykazać, że uważała Łotwę za tymczasową ojczyznę (pagaidu dzimtene). Zarzucał Niemcom bałtyckim bliskie stosunki z III Rzeszą, podkreślanie swojej przynależności do wspólnego narodu niemieckiego i traktowanie Łotyszy tylko jako obywateli, z którymi zamieszkują jedno terytorium. W konsekwencji Bērzins twierdził, że Niemcy bałtyccy są elementem obcym dla narodu łotewskiego, który nie powinien liczyć się z odrębnymi interesami ludzi niewiążących swojego losu z losem państwa łotewskiego i - często - nienawidzących go. Bērzins podkreślał, że Łotwa nie może dopuścić do tego, by mniejszość niemiecka kultywowała separatyzm z pomocą III Rzeszy ${ }^{24}$.

Główne prawa mniejszości narodowych dotyczyły szkolnictwa. Nic dziwnego, że pierwszym krokiem rządu Ulmanisa w polityce narodowościowej była właśnie zmiana przepisów ustawy o szkolnictwie mniejszości z 1919 r. Po długim, dwunastogodzinnym posiedzeniu rządu, 12 lipca 1934 r. przyjęto nowe prawo o szkolnictwie publicznym. Dotyczyło ono także szkół mniejszości narodowych ${ }^{25}$.

Preambuła nowego prawa o szkolnictwie kładła nacisk na wychowanie uczniów w duchu narodowym, choć jednocześnie podkreślała, że jednym z zadań instytucji kształcących jest wychowanie młodych ludzi w duchu współpracy narodów i klas.

22 Rigasche Rundschau 14 VII 1934: 2.

23 H. Stegman, „Aus meinen Erinnerungen”, „Stadtverordneter in Riga (1920-1933)”, Baltische Hefte 7 (1960-1961): 93.

24 Jaunākās Zinas 19 I 1935: 2.

25 Wolfgang Wachtsmuth, Wege, Umwege, Wegenossen. Lebenserinnerungen eines Balten 1876-1950 (München: Winkler, 1954), 240. 
Mniejszości narodowe nadal mogły utrzymywać swoje szkoły, i to zarówno prywatne, jak i publiczne, ale ustawa nakładała restrykcje na przyjmowanie do nich niektórych grup uczniów. Przede wszystkim dzieci z małżeństw mieszanych, gdzie jeden z rodziców był narodowości łotewskiej, musiały być obowiązkowo posyłane do szkół łotewskich. W pozostałych przypadkach narodowość dzieci z małżeństw mieszanych określano na podstawie narodowości ojca. To z kolei determinowało narodowy typ szkoły, do jakiej dziecko było oddawane (artykuł 7). Językiem nauczania w szkolnictwie mniejszości był nadal język ojczysty danej mniejszości, ale zasada ta nie dotyczyła publicznych szkół zawodowych, w których można było nauczać wyłącznie po łotewsku (artykuł 22). Nowa ustawa była także mniej liberalna odnośnie do obowiązku utrzymywania szkół mniejszości przez państwo i samorządy. Odtąd dotyczyć to miało tylko szkół podstawowych, które liczyły przynajmniej 60 uczniów, i szkół średnich mających co najmniej 75 uczniów. Jeżeli liczba uczniów w danej placówce oświatowej była niższa od przewidzianego minimum przez dwa lata z rzędu, to szkoła taka miała być zamknięta (artykuł 83) ${ }^{26}$.

Nowe prawo nie wspominało nic o dotychczasowych urzędach mniejszości kierujących ich szkolnictwem. Krótko mówiąc, organom tym polecono przerwać swoją działalność. Rząd ustanowił natomiast stanowisko urzędnika ds. szkolnictwa mniejszości, po jednym dla każdej grupy narodowej. Jednakże ci ludzie byli faktycznie pozbawieni wszelkiego znaczenia. Nie mieli ani własnej kancelarii, ani nie mogli rejestrować otrzymywanych listów. Wszystkie sprawy szkół mniejszości zostały przekazane odpowiednim departamentom Ministerstwa Oświaty, a wspomniani wyżej urzędnicy mogli co najwyżej pełnić rolę doradców, co w praktyce było rzadkością. Nie mieli zresztą nawet prawa utrzymywania korespondencji ze swoimi szkołami. Jednak, jak na ironię losu, sytuacja Niemców byłą nieco lepsza. Stanowisko urzędnika ds. szkolnictwa niemieckiego objął Max von Radecky, który zdołał dojść do porozumienia z ministrem oświaty, Augustem Tentelisem, skądinąd człowiekiem negatywnie nastawionym do Niemców, i był przynajmniej przyjmowany i wysłuchiwany przez niego, w przeciwieństwie do urzędników pozostałych mniejszości narodowych ${ }^{27}$.

Wkrótce po opublikowaniu tej ustawy władze łotewskie wydały wiele innych rozporządzeń związanych ze szkolnictwem mniejszości. Przede wszystkim łotewski program nauczania został wprowadzony dla wszystkich przedmiotów. Niemcy znowu jednak znaleźli się w lepszej sytuacji niż pozostałe mniejszości narodowe. Dzięki zabiegom von Radeckiego rozporządzenie to nie dotyczyło programu nauczania języka niemieckiego i łotewskiego w szkołach niemieckich. Szkolnictwo niemieckie dotknął za to w dużym stopniu zakaz używania niektórych podręczników. Co więcej, nie wolno też było opracowywać nowych podręczników. Skutkiem tego poziom nauczania w szkołach niemieckich znacznie się obniżył.

26 Sprawy narodowościowe 4 (1934): 482-483.

27 Wachtsmuth, Wege, 240. 
Czternastoletni uczniowie nie wiedzieli, że Berlin jest stolicą Niemiec i nie słyszeli

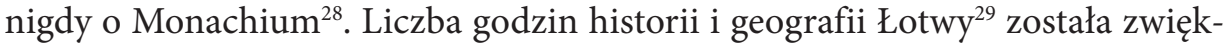
szona kosztem lekcji historii i geografii powszechnej (odpowiednio 6 i 5 oraz 3 i 4 godziny).

Po 1934 r. nauczycieli mianowały władze łotewskie bez pytania o zgodę mniejszości narodowych. Jeżeli chodzi o nauczycieli języka łotewskiego oraz historii i geografii Łotwy, mogli nimi zostać tylko Łotysze ${ }^{30}$.

Nowa polityka edukacyjna reżimu Ulmanisa wobec mniejszości narodowych spowodowała gwałtowny spadek liczby uczniów, a w konsekwencji klas i samych placówek oświatowych. W sumie mniejszości tylko w ciągu jednego tylko roku po wydaniu tej ustawy straciły 93 szkoły, a więc prawie jedną czwartą (pozostało 355 placówek oświatowych ${ }^{31}$. Jeżeli chodzi o niemieckie placówki oświatowe, spadek ten wynosił prawie $10 \%$. Niemcy bałtyccy w ciągu roku po wydaniu tej ustawy stracili sześć szkół podstawowych (z dotychczasowych 65) i dwie średnie (z dotychczasowych

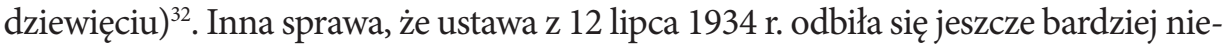
korzystnie na szkolnictwie pozostałych mniejszości narodowych. W szczególności było to widoczne w przypadku żydowskich i białoruskich szkó średnich, które straciły odpowiednio 40 i 52\% uczniów. W przypadku rosyjskich szkół średnich spadek wyniósł tylko $2 \%$, a polskie szkoły tego typu liczyły w 1935 r. nawet o sześciu uczniów więcej, ale należy pamiętać, że polskie szkolnictwo średnie na Łotwie było słabo rozwinięte i miało zaledwie 268 uczniów ${ }^{33}$. Później i tak nastąpił tutaj spadek, i to bardzo wyraźny, gdyż w roku szkolnym 1936/37 do dwóch polskich gimnazjów uczęszczało zaledwie 178 uczniów. W szkolnictwie podstawowym największe straty ponieśli Polacy w Łatgalii, gdzie większość ich szkół została zamknięta. W roku szkolnym 1936/37 liczba polskich szkół podstawowych, łącznie z tymi w Rydze, wynosiła 18 - przed 1935 r. było ich 30, a uczyło się w nich 2279 uczniów, czyli trzykrotnie mniej niż w niemieckim szkolnictwie podstawowym (6502), co, jak pamiętamy, nie odpowiadało w żadnym przypadku proporcjom ludności ${ }^{34}$. W pierwszym roku po wydaniu ustawy szkolnej zamknięto w sumie, jak już zaznaczyłem, 93 placówki oświatowe mniejszości narodowych ${ }^{35}$. Oznaczało to, że straty Niemców nie były aż tak duże, gdyż tylko $10 \%$ zamkniętych szkół to szkoły niemieckie. W dalszym ciągu mniejszość niemiecka na Łotwie

28 H. Wolff, Die Rechtsbrücke zum Nachteil der deutschen Volksgruppe in Lettland 1919-1936 (Berlin-Dahlen, bez daty wyd.), 120-121.

29 Wolfgang Wachtsmuth, Von deutscher Arbeit in Lettland 1918-1934, Band 2 (Köln: Comel, 1952), 405-406.

30 Wolff, Die Rechtsbrücke, 120.

31 Latvijas skaițos, 80.

32 Baltische Monatsschrift LXVI (1935): 676.

33 Rits, 31 VIII 1935.

34 Agnis Balodis, Latvijas un latviešu vēsture (Rīga: Neatkarīgā teātra „Kabata” grāmata apgāds, 1991), 229.

35 Łossowski, „National Minorities in the Baltic States”, Acta Poloniae Historica XXIII (1972): 99-100. 
miała nieproporcjonalnie dużo szkół podstawowych i średnich w porównaniu z pozostałymi mniejszościami narodowymi. W roku szkolnym 1936/37 niemieckie szkoły podstawowe stanowiły ponad $20 \%$ ogółu tego typu placówek oświatowych mniejszości, a szkoły średnie nawet jedną trzecią, gdy tymczasem ludność niemiecka to zaledwie około 12\% ludności niełotewskiej. Ta nadreprezentacja dotyczyła także uczniów szkół niemieckich (tym razem narodowości prawie wyłącznie niemieckiej), w mniejszym stopniu podstawowych (17\%), a w znacznie większym - średnich $(33 \%)^{36}$, i to wszystko mimo faktu, iż rodziny niemieckie miały bardzo mało dzieci.

Tak więc mimo antyniemieckich nastrojów zarówno w rządzie łotewskim, jak i wśród opinii publicznej władze łotewskie nie zdecydowały się podjąć bardziej zdecydowanych kroków, aby wyraźniej ograniczyć szkolnictwo mniejszości niemieckiej. Co więcej, uczyniły nawet pewne ustępstwa na rzecz strony niemieckiej. Oto jeszcze jeden przykład. Latem 1935 r. samorząd municypalny w Dźwińsku cofnął finansowe wsparcie dla lokalnej niemieckiej szkoły podstawowej, która w związku z tym została zamknięta. Prośba o otwarcie nowej została odrzucona, ponieważ strona łotewska nie chciała ustanowić precedensu, a to z uwagi na Polaków, którzy byli naturalnie dla władz łotewskich wrogiem numer jeden w Łatgalii. Negocjacje ciągnęły się pół roku, aż w końcu znaleziono wyjście. Samorząd zgodził się na powtórne otwarcie tej szkoły jako komunalnej, lecz faktycznie była ona utrzymywana za pieniądze prywatne, tj. samych Niemców ${ }^{37}$.

Wkrótce po przewrocie Ulmanisa władze łotewskie wydały, też 12 lipca 1934 r., nowe zarządzenia językowe. Na ich mocy łotewski był jedynym językiem dopuszczonym do używania na poczcie i telegrafie. Osoby, które go nie znały, mogły zwracać się do naczelnika danej placówki, by wyznaczył im tłumacza. Listy zaadresowane w obcym języku miały być zwracane nadawcom, przy czym nadgorliwi urzędnicy pocztowi stosowali często tę zasadę również w korespondencji międzynarodowej ${ }^{38}$. Używanie języka niełotewskiego na zgromadzeniach otwartych, tj. takich, w których mogli uczestniczyć zarówno członkowie, jak i osoby postronne, $w$ wystąpieniach publicznych i imprezach było odtąd możliwe wyłącznie za zgodą ministra spraw wewnętrznych ${ }^{39}$.

W urzędach państwowych jedynym językiem komunikacji był odtąd łotewski. W sądach, w niektórych przypadkach, osoby, które nie władały tym językiem, mogły posługiwać się językiem ojczystym. Po 1934 r. nazwy ulic w dwóch czy tym bardziej trzech językach zostały definitywnie zakazane ${ }^{40}$.

36 Balodis, Latvijas, 229.

37 Politisches Archiv des Auswärtigen Amtes (PAAA), Berlin, Akten der deutschen Gesadtschaft in Riga, 159/2, Zur Lage der deutschen Schulen Lettlands. Ergänzung zum Bericht vom Dezeber 1937, s. 4.

38 Edgar Tatarin-Tarnheyden, „Politizierung der Post in den Baltischen Staaten”, Völkerbund und Völkerrecht 11 (1934/35): 608.

39 Sprawy narodowościowe 2 (1934): 482.

40 Edgar Tatarin-Tarnheyden, „Autokratische Regierungen in Lettland und Estland und deren völkische Politik", Archiv des öffentlichen Rechts VXY: 299, 303. 
Rozwiązania te miały charakter prowizoryczny. W styczniu 1935 r. ukazała się nowa ustawa językowa, obejmująca całokształt spraw. Oprócz rozwiązań już wymienionych, wprowadzała obowiązkowe użycie języka łotewskiego $\mathrm{w}$ instytucjach prywatnych, o ile posiadały osobowość prawną (np. domach handlowych, przedsiębiorstwach przemysłowych i transportowych). Wszystkie pisemne umowy, zobowiązania, długi musiały być sporządzone po łotewsku (w przeciwnym wypadku były nieważne). Wszelkie programy, plakaty, ogłoszenia, nalepki z cenami czy nazwami firm i marek musiały być drukowane po łotewsku. Pieczątki organizacji, instytucji gospodarczych i osób prywatnych musiały być również w języku łotewskim, choć minister spraw wewnętrznych mógł dopuścić też inny język. Nazwa każdej bez wyjątku miejscowości musiała być podawana w języku łotewskim. Instytucje samorządowe mogły wprawdzie używać języka danej mniejszości, lecz tylko w przypadku, gdy stanowiła ona ponad 50\% mieszkańców w danym rejonie. W praktyce zastrzeżenie to odnosiło się tylko do Rosjan, gdyż w niektórych gminach na południowym-wschodzie kraju stanowili oni większość mieszkańców. Nowa ustawa kładła także kres używaniu gotyckiego pisma łotewskiego, narzucając alfabet łaciński tym periodykom, które ukazywały się częściej niż raz w tygodniu. W ten sposób władze łotewskie chciały ograniczyć do minimum ślady kultury niemieckiej w życiu kulturalnym Łotyszy ${ }^{41}$.

To, co drażniło Niemców w szczególności, to dość liczne przypadki przymusowej łotyszyzacji nazwisk przez nadgorliwych urzędników (np. Šumans zamiast Schumann). Zjawisko to dotyczyło nawet kart wizytowych ${ }^{42}$. Niemcy byli też oburzeni faktem, że nie mogli używać starych, niemieckich nazw miejscowości ${ }^{43}$.

Restrykcje dotknęły także życia kulturalnego mniejszości narodowych. Nowa ustawa o drukarniach, bibliotekach, czytelniach oraz o handlu książkami i gazetami przewidywała, że osoby chcące założyć i kierować tego typu placówkami musiały władać językiem łotewskim i otrzymać pozwolenie ministra. Co więcej, to pozwolenie mogło być w każdym czasie cofnięte bez podania jakiejkolwiek przyczyny. Ponadto paragraf 21 zakazywał wystawiania publikacji w obcych językach w witrynach sklepów oraz w poczekalniach, np. u lekarzy czy w szpitalach, w większej liczbie niż wydawnictwa łotewskie ${ }^{44}$.

Pogorszeniu uległa też sytuacja księgarń, zwłaszcza niemieckich. Było to związane z licznymi restrykcjami nałożonymi na nie. Zaledwie jedna księgarnia niemiecka otrzymała licencję na import książek. Stołeczne szkoły niemieckie nie mogły dłużej zamawiać podręczników w niemieckich księgarniach, a to dlatego, że lokalne władze opublikowały listę tych księgarni, które mogły dostarczać

41 Rigasche Rundschau 7 I 1935: 1.

42 Tatarin-Tarnheyden, Autkokratische, 299.

43 J.G. Herder-Institut, Archiv, Marburg, HIB 218: A. Intelmann, Auszüge aus meinem Tagebuch, 3.

${ }^{44}$ Wolff, Die Rechtsbrücke, 128. 
szkołom podręczniki i naturalnie nie było na niej żadnej księgarni niemieckiej. Podobne zarządzenie dotyczyło nawet przyborów piśmiennych dla szkół ${ }^{45}$.

Wyraźnie spadła też liczba gazet i czasopism publikowanych na Łotwie po przewrocie Ulmanisa. O ile w 1933 r. ukazywało się 12 gazet niemieckich, 13 rosyjskich, $11 \mathrm{w}$ języku hebrajskim i jidysz oraz $3 \mathrm{w}$ polskim, to pięć lat później te dane wynosiły odpowiednio: 8, 4, 3. W 1938 r. nie ukazywała się już żadna polska gazeta. Jeszcze większy trend spadkowy można było zaobserwować na rynku wydawniczym czasopism. W 1933 r. ukazywały się 22 czasopisma niemieckie, 13 rosyjskich i 1 polskie. Pięć lat później już zaledwie 8 niemieckich i 3 rosyjskie (Polacy zdołali zachować jedyne czasopismo). Sprawą dyskusyjną jest natomiast to, w jakim stopniu na ten wyraźnie spadkowy trend miała aktualna polityka narodowościowa władz łotewskich po 15 maja 1934 r., gdyż tendencja spadkowa dotknęła w jeszcze większym stopniu łotewskie wydawnictwa periodyczne. O ile w 1933 r. ukazało się 116 łotewskich gazet i 189 czasopism, to w 1938 r. zaledwie, odpowiednio, 36 i $132^{46}$. Niewątpliwie jedną z głównych przyczyn była polityka rządu, który nie tolerował opozycyjnych wydawnictw. Zawieszenie lub zamknięcie organizacji pociągało za sobą podobne kroki w stosunku do ich organów prasowych. To właśnie dlatego Polacy stracili wszystkie trzy gazety. Poza tym było rzeczą niezmiernie trudną uzyskać koncesje na wydawanie nowych periodyków ${ }^{47}$. Jednocześnie trzeba jednak zaznaczyć, że i finansowe trudności przyczyniały się do likwidacji niektórych gazet. Było to główną przyczyną zaprzestania publikowania na początku 1939 r. „Libausche Zeitung i Deutscher Bote"48.

Jeżeli chodzi o publikację książek i broszur, to sytuacja była bardziej skomplikowana. Z jednej strony ich liczba wzrastała również po przewrocie w $1934 \mathrm{r}$., z drugiej - łączny nakład zwartych wydawnictw mniejszościowych spadał. Najwyraźniej widać tę tendencję w obszarze publikacji polskich: z 9000 egzemplarzy w 1933 r. do $6150 \mathrm{w} 1937$ r.; dla niemieckich dane te wynosiły odpowiednio 106440 i 83 485, a dla rosyjskich - 108950 i 90 140. Dla porównania, łączny nakład zwartych wydawnictw łotewskich wzrósł wówczas o prawie 100\% (z 1613270 do 3079447$)^{49}$.

Inną dziedziną, która ucierpiała przez narodowościową politykę rządu Ulmanisa, były zbiory kulturalne. Najbardziej dotknęło to Niemców bałtyckich, którzy do początków XX w. odgrywali na tych ziemiach dominują rolę kulturalną. Łotewska Państwowa Administracja Ochrony zabytków 5 września 1935 r. podjęła decyzję o przejęciu manuskryptów i map z biblioteki Towarzystwa Historii i Starożytności w Rydze oraz z Muzeum Katedralnego, powołując się na paragraf 20 ustawy

45 Bundesarchiv, Berlin-Lichterfelde, Deutsche Stiftung, R 8043, 42/1, betrifft, Lage des deutschen Buchhandels in Lettland, 398.

46 Latvijas statistika gada grāmata, 1937/1938 (Rīga: Valsts Statistika Parvalde, 1939), 63.

47 Sprawy narodowościowe 2 (1934): 481.

48 Wolff, Die Rechtsbrücke, 128.

49 Latvijas statistika, 1933 (Rīga 1934), 45; ibidem, 1937 (Rìga 1938), 61. 
o ochronie zabytków, który głosił, że ma ona prawo przejmować zbiory kulturalne, po uzgodnieniu z Ministerstwem Oświaty, o ile dotychczasowy właściciel nie jest w stanie przechowywać ich zgodnie z obowiązującymi przepisami. Naturalnie był to tylko pretekst. Duża liczba dokumentów i map została przekazana Łotewskiemu Archiwum Państwowemu. Przewieziono tam m.in. siedem skrzyń materiałów archiwalnych dotyczących landeswery ${ }^{50}$. Ten krok był tylko preludium do bardziej dalekosiężnych zarządzeń. Władze łotewskie były zdeterminowane położyć kres istnieniu niemieckiego Muzeum Katedralnego, jednego z największych i najcenniejszych na całej Łotwie. W tym celu postanowiły wykorzystać fakt, że niewielka część jego zbiorów (615 eksponatów na 76 000) była własnością miasta Rygi ${ }^{51}$. Muzeum Katedralne zostało zlikwidowane w 1936 r., a jego zbiory przejęte przez Ryskie Muzeum Historyczne i Muzeum Wojny ${ }^{52}$.

Jeżeli chodzi o towarzystwa naukowo-kulturalne, ich los był niepewny w związku z ustanowieniem 5 maja 1938 r. Izby Literatury i Sztuki. Liczyła ona 100 członków, wśród których byli też przedstawiciele mniejszości narodowych - czterej Niemcy, trzej Rosjanie, dwaj Żydzi i jeden Polak ${ }^{53}$. Obronną ręką wyszli z tego Niemcy, gdyż Ulmanis zaproponował afiliację ich towarzystw z Instytutem Herdera w Rydze, na co skwapliwie się zgodzili ${ }^{54}$.

Były jednak pewne obszary aktywności kulturalnej mniejszości, które nie ucierpiały. Przede wszystkim dotyczyło to życia teatralnego. W samej tylko Rydze działały nadal dwa niemieckie teatry, dwa rosyjskie, dwa żydowskie, jeden polski i jeden litewski. Z tych teatrów mniejszości największe znaczenie miały jednak tylko dwa teatry dramatyczne: niemiecki i rosyjski ${ }^{55}$.

W 1939 r. pojawiły się słabe symptomy zmiany w polityce kulturalnej względem mniejszości narodowych. Znalazło to wyraz m.in. w tym, że po raz pierwszy mniejszości zostały zaproszone do wzięcia udziału w Łotewskim Tygodniu Kulturalnym. Ta impreza kulturalna była organizowana corocznie, począwszy od 1935 r., ale prezentowane były dotychczas wyłącznie łotewskie osiągnięcia kulturalne. Łotewski Tydzień Kulturalny w 1939 r. został opatrzony hasłem wspólnych zadań kulturalnych na ziemi łotewskiej. I tak Niemcy pokazali wystawę pt. „Niemiecka Twórczość Kulturalna na Łotwie", otwartą w Domu Czarnogłowych w Rydze

50 Bundesarchiv, Berlin-Lichterfelde, Deutsche Stiftung, R 8043, 42/1, Aufzeichnung über die Beschlagnahme der Handschriftenund Kartensammlungen der Bibliothek der Gesellaschaft für Geschichte und Altertumskunde zu Riga und Rigaer Dommuseum vom 5. September 1935 durch die lettländische Denkmalsverwaltung, 4070412.

${ }^{51}$ Bernhard Hollander, „Unser Dommuseum”, Baltische Monatsschrift 5 (1936): 251.

52 Baltische Monatsschrift 7 (1937): 46.

53 Wolff, Die Rechtsbrücke, 129.

54 W. Klumber, Ein Beitrag zur Kulturpolitik im Nordostraum. Ein Rückblick1919-1939 (Königsberg, bez daty wyd.), 28 .

55 Lācis, Latviešu zemes, 302; H. Grussendorf, „Rigas deutsche Bühne und ihre Wirkung feld”, Baltische Monatsschrift 11 (1937): 660. 
29 stycznia $1939 \mathrm{r}^{56} \mathrm{Z}$ kolei prezydent Ulmanis zdecydował się na przyjazny gest wobec szkolnictwa niemieckiego, które dotychczas nie cieszyło się jego poparciem. Z okazji piątej rocznicy tzw. Przyjaznego Wyzwania podarował 199 książek 10 niemieckim szkołom ${ }^{57}$.

Polityka narodowościowa reżymu Ulmanisa objęła także stosunki religijne. Łotwa była krajem wielowyznaniowym. Większość jej mieszkańców była wyznania luterańsko-ewangelickiego. Dotyczyło to głównie Łotyszy (mieszkających poza Łatgalią) i Niemców. Prymat Niemców w Kościele Luterańsko-Ewangelickim został jednak złamany już u progu niepodległości państwa łotewskiego. Teraz nie było już więc wiele do zrobienia. Rząd ograniczył się do wprowadzenia czysto łotewskiej liturgii do nabożeństw w kościołach łotewskich w miejsce tekstów będących tłumaczeniem z niemieckiego ${ }^{58}$.

Inaczej przedstawiała się sytuacja z Kościołem katolickim i Cerkwią prawosławną. Katolikami byli przede wszystkim mieszkańcy Łatgalii, a jeżeli chodzi o narodowości, to: Polacy, Łotysze i w pewnym stopniu Białorusini. Wpływy polskie i polskości w Kościele katolickim na niepodległej Łotwie były bardzo wyraźne. Nic więc dziwnego, że rząd Ulmanisa postanowił temu przeciwdziałać. Początkowo próbował stosować mocne środki nacisku, zmierzające właśnie do wyeliminowania z Kościoła wpływów polskich. Już w końcu maja zakazano kolportowania na Łotwie pism „Przewodnik Katolicki” i „Rycerz Niepokalanej”. Natrafiwszy jednak na zdecydowany opór, władze łotewskie, skrępowane na dodatek konkordatem, poszły na kompromis. W trakcie spotkania Ulmanisa z arcybiskupem Antonim Springovičsem w klasztorze Aglona (który do dziś jest głównym katolickim miejscem pielgrzymkowym na Łotwie) 18 sierpnia 1934 r. ustalono modus vivendi. Odtąd oficjalnie łotyszyzacji Kościoła katolickiego nie prowadzono, ale walka oddolna, zmierzająca do ukrócenia w nim wpływów polskich, toczyła się dalej59.

Prawosławni na Łotwie to w pierwszym rzędzie Rosjanie, ale także Białorusini i sami Łotysze. Na 174 tysięcy wyznawców tej religii ci ostatni stanowili bądź co bądź aż 62 tysiące. W dziele łotyszyzacji Cerkwi prawosławnej władze znalazły zwolennika w osobie samego arcybiskupa Jānisa Pommersa. To z kolei wzbudziło ostry sprzeciw w środowiskach rosyjskich, zwłaszcza emigracyjnych (nie zapominajmy, że na małej Łotwie mieszkało w 1930 r. aż 10 tysięcy „białych” Rosjan $\left.{ }^{60}\right)$. W połowie października 1934 r. Pommers został zamordowany, prawdopodobnie przez emigrantów rosyjskich z Paryża (morderców nigdy nie ujęto, ale Pommers został w 2001 r. kanonizowany i jest tym samym jedynym łotewskim

\footnotetext{
56 Rigasche Rundschau 2 I 1939: 1.

57 Ibidem.

58 Łossowski, „Problem mniejszości narodowych w Europie Środkowo-Wschodniej na przykładzie państw bałtyckich 1919-1940”, w Ład wersalski w Europie Środkowej (Wrocław: Zakład Narodowy im. Ossolińskich, 1971), 137.

59 Łossowski, Kraje bałtyckie, 260.

60 Istorija Rossiji XX wiek 1894-1939 (Moskwa: Astriel, 2011), 831.
} 
świętym). Wówczas władze narzuciły, nie cofając się przed metodami szantażu, wybór na metropolitę Augustinsa Petersonsa, który prowadził jeszcze skrajniejszą politykę łotyszyzacji Cerkwi. Nowy metropolita wyznaczył sobie zadanie uczynienia języka łotewskiego językiem liturgicznym Cerkwi i w tym celu polecił przygotowywać do tego duchownych, organizując specjalne kursy. Jednocześnie zarząd spraw wyznaniowych, łamiąc opór duchowieństwa, przeprowadził oddzielenie Cerkwi od patriarchatu moskiewskiego i podporządkowanie go patriarchatowi w Konstantynopolu ${ }^{61}$.

Reżym Ulmanisa ograniczył także wpływ mniejszości narodowych na życie gospodarcze Łotwy. Nową politykę ekonomiczną rządu łotewskiego należy rozpatrywać w szerszym kontekście. Rząd Ulmanisa walczył ze skutkami wielkiego kryzysu. Aby je przezwyciężyć, zainicjował politykę zmierzającą do wzmocnienia pozycji państwa w życiu gospodarczym. Niektóre środki były tak dalekosiężne, że gospodarkę Łotwy zaczęto określać mianem państwowego kapitalizmu. Oczywiście rosnąca ingerencja państwa w życie ekonomiczne kraju musiała doprowadzić do ograniczenia sektora prywatnego i uczynienia go zależnym od administracji państwowej, co także obniżało pozycję mniejszości narodowych, a zwłaszcza niemieckiej i żydowskiej.

Państwo łotewskie otrzymało szerokie możliwości ingerowania w gospodarkę wraz z wydaniem ustawy o Łotewskim Banku Kredytowym (Latvijas Kreditbanka) 9 kwietnia 1935 r. oraz przepisów uzupełniających 3 października 1935 r. Odtąd rząd miał prawo rozwiązać każdą jednostkę gospodarczą, która zalegała ze spłatą podatków czy kredytów, o ile wymagał tego interes lub ochrona państwa. W takiej sytuacji Łotewskiemu Banku Kredytowemu Rada Ministrów polecała likwidację danego podmiotu gospodarczego. Potężny bank, którego głównym udziałowcem było państwo, oceniał aktywa likwidowanego przedsiębiorstwa, a w razie stwierdzenia nadwyżek wypłacał akcjonariuszom ich udziały nie w gotówce, lecz w państwowych obligacjach hipotecznych. W ten sposób Łotewski Bank Kredytowy zlikwidował do 1 stycznia 1937 r. 19 instytucji kredytowych, 14 domów handlowych i przedsiębiorstw przemysłowych. Dwa lata później liczba ta wzrosła do 47 przedsiębiorstw i 180 spółdzielni. Łotewski Bank Kredytowy zlikwidował m.in. trzy duże banki niemieckie, a mianowicie Ryski Bank Handlowy (Rigaer Handelsbank), Ryski Bank Kredytowy (Rigaer Creditsbank) i Ryski Bank Kupiecki (Rigaer Kaufmännischer Bank). W 1939 r. istniał już tylko jeden duży bank niemiecki - Bank Libawski (Libauer Bank), który był jednak zależny od Dresdner Bank, a więc od kapitału z III Rzeszy ${ }^{62}$.

Najwięcej stracili jednak Żydzi, będący najsilniejszym dotychczas elementem w bankowości Łotwy. Inna sprawa, że kapitał likwidowanych banków był w większej części zagraniczny. Głównymi beneficjentami tych zmian byli Łotysze, a ściślej

61 Łossowski, Kraje bałtyckie, 259-260.

62 Wolff, Die Rechtsbrücke, 76-78. 
mówiąc, państwo łotewskie. O ile w 1934 r. 16\% kapitału bankowego znajdowało się w rękach Łotyszy, to trzy lata później - aż $91 \%{ }^{63}$. Tak więc polityka władz łotewskich nie powinna być postrzegana tylko jako ograniczenie pozycji mniejszości narodowych w systemie bankowym. Przede wszystkim rząd łotewski chciał wyrwać Łotwę ze „szponów” międzynarodowego, głównie żydowskiego, kapitału.

Państwo łotewskie przejmowało także towarzystwa ubezpieczeniowe, zwłaszcza mniejszości narodowych. Dotyczyło to również najstarszego z nich, I Ryskiego Towarzystwa Ubezpieczeniowego (I Rigaer Versicherungsgesellschaft), istniejącego od 1784 r. i będącego dotychczas własnością Niemców bałtyckich ${ }^{64}$.

Łotewski Bank Kredytowy zlikwidował wiele przedsiębiorstw przemysłowych. Znowu charakterystyczną rzeczą było to, iż w pierwszym rzędzie zamykał fabryki $z$ kapitałem zagranicznym ${ }^{65}$. Tym razem to jednak najwięcej stracili Niemcy bałtyccy, przynajmniej w porównaniu z pozostałymi mniejszościami narodowymi. Tylko w latach 1934-1936 liczba ich wszystkich podmiotów gospodarczych spadła o 99, gdy tymczasem pozostałych mniejszości narodowych wzrosła o 431, nie mówiąc już o Łotyszach (wzrost o 1368). W rezultacie Niemcy bałtyccy posiadali tylko $4,7 \%$ podmiotów gospodarczych, a pozostałe mniejszości aż 38,2\%. Naturalnie większość tych podmiotów gospodarczych była w rękach Żydów. W szczególności dotyczyło to handlu. Żydzi byli właścicielami 27205 sklepów i innych instytucji handlowych, zatrudniających 51821 pracowników, co stanowiło jedną czwartą tego typu placówek i osób tam zatrudnionych na Łotwie. Niemcy posiadali tylko 5,5\% placówek handlowych, które zatrudniały jednak 8,4\% pracowników tej branży ${ }^{66}$.

Rząd łotewski postanowił położyć też kres dominacji mniejszości narodowych w firmach eksportowych i spedycyjnych. Przed 1937 r. większość ich była w rękach Niemców bałtyckich. Począwszy od 1 stycznia 1937 r., firmy te mogły kontynuować swoją pracę pod warunkiem, że uzyskały koncesje, które były nadawane przez Urząd Celny po uzgodnieniu z Izbą Handlowo-Przemysłową na jeden rok, przy czym opłata była bardzo wysoka i wahała się od 1500 do 6000 łatów. Rząd motywował oficjalnie ten krok zbyt dużą liczbą tego typu firm na rynku. Wielu Niemców nie otrzymało koncesji i było zmuszonych połączyć swoje firmy z tymi, którym się to udało ${ }^{67}$.

Rząd łotewski 14 grudnia 1937 r. wydał ustawę o przedstawicielach obcych firm na Łotwie. Odtąd mogli być nimi tylko dealerzy, o ile otrzymali pozwolenie Izby Handlowo-Przemysłowej. Zarządzenie to dotknęło także lokalnych Niemców i Żydów, ponieważ to oni właśnie byli zatrudniani przez firmy zagraniczne, głównie niemieckie i angielskie ${ }^{68}$.

${ }^{63} \quad$ Ibidem, 78.

64 Ibidem, 93.

65 Arnolds Aizsilnieks, Latvijas saimniecība vēsture 1918-1945 (Stockholma: Daugava, 1968), 731.

${ }_{66}$ Bundesarchiv, Berlin-Lichterfelde, Deutsche Stiftung, R 8043, 42/1, Dem Unternehmungsgeist der Letten bieten sich im Handel noch viele Mőglichkeiten, 190.

67 Ibidem, Übersicht über die Speditionsgesellschaften in Lettland, 54.

68 Ibidem, Lettland. Deutsche Exportfirmen zur Beachtung, 186-187. 
Władzom łotewskim zależało też na osłabieniu pozycji mniejszości na rynku nieruchomości. Już 5 kwietnia 1934 r., a więc na kilka tygodni przed przewrotem Ulmanisa, wydano ustawę dotyczącą sprzedaży nieruchomości, w tym ziemi, poza miastami. Odtąd każda taka transakcja wymagała zgody Ministerstwa Sprawiedliwości. Ustawa z 25 lutego 1935 r. rozciągała to także na nieruchomości znajdujące się na terenie miast. Formalnie, ten krok miał zapobiegać spekulacji, lecz faktycznie nowa ustawa była używana przeciw mniejszościom narodowym. Rozporządzenia te zostały uzupełnione przez ustawę z 10 marca 1938 r., na mocy której Państwowy Bank Ziemski (Valsts Zemes Banka) otrzymał prawo pierwokupu we wszystkich transakcjach sprzedaży-kupna nieruchomości w strefie $50 \mathrm{~km}$ od granicy państwa lub wybrzeża, a więc na większości terytorium Łotwy, w tym, co istotne, Rygi. Ta ostatnia ustawa była skierowana w szczególności przeciw mniejszościom ${ }^{69}$.

Mniejszości narodowe straciły też swoje organizacje ekonomiczne i społeczno-zawodowe. Naturalnie, ten sam los spotkał i odpowiednie organizacje łotewskie, trzeba jednak pamiętać, że dzięki rzeczonym organizacjom mniejszości, a zwłaszcza Niemcy bałtyccy, mogły pielęgnować i utrzymywać swoją odrębność narodową. Było to związane z wprowadzeniem izb państwowych, które wzorowano na faszystowskich korporacjach włoskich (w 1935 r. pracownicy poselstwa łotewskiego w Rzymie zajmowali się dosłownym tłumaczeniem ustaw korporacyjnych). Dnia 31 grudnia 1935 r. opublikowano tzw. ustawy sylwestrowe. Na ich mocy powołano do życia Izbę Przemysłowo-Handlową i Izbę Rzemieślniczą. Jednocześnie ustawy przewidywały rozwiązanie organizacji prywatnych i nieobliczonych na przynoszenie zysku związanych z tymi dziedzinami życia gospodarczego w ciągu trzech miesięcy ${ }^{70}$. Skutkiem tego m.in. Niemcy stracili najważniejsze organizacje, niejednokrotnie mające długą tradycję. Najbardziej bolesną stratą było bez wątpienia rozwiązanie dwóch ryskich gildii: dużej (Mariengilde) i małej (Johannisgilde). Oprócz tego zlikwidowano dwie gildie w Libawie. Rozwiązaniu uległy też: Związek Kupców Niemieckich w Rydze (Verein deutscher Kaufleute in Riga), Ryski Związek Fabrykantów (Rigaer Fabrikantenverein), Ryski Związek Niemieckich Właścicieli Domów (Rigaer deutscher Hausbesitzerverein), Związek Kupiecki w Rydze (Kaufmännischerverein in Riga) oraz związki rzemieślnicze w Bauska, Libawie, Mitawie, Windawie i Goldyndze ${ }^{71}$. Jak już zaznaczyłem, nie tylko niemieckie instytucje prywatne uległy likwidacji. To samo dotyczyło także łotewskich, lecz ich majątek był na ogół niewielki ${ }^{72}$. Niemcy stracili natomiast duży majątek. W szczególności odnosiło się to do ryskich gildii (w sumie 25000000 łatów) ${ }^{73}$.

69 Wolff, Die Rechtsbrücke, 75.

70 Pèdèjā Brìdī 1 I 1936: 9.

71 PAAA, Akten der deutschen Gesandschaft in Riga, 151/2, Gilden, Gewerbvereine usw., Verzeichnis der durch die lettländischen Wirtschaftskammergesetze vom 31. Dezember 1935 der Liquidation unterlegendenbezw. Von der Liquidation bedrohten der deutschen Organizationen, 1-5.

72 Ibidem, 151/2, Einzelstück, 2.

73 Ibidem, 151/2, Gilden, 1. 
Mniejszość niemiecka straciła także, w związku z ustanowieniem w kwietniu 1936 r. Izby Rolniczej, jedną z dwóch organizacji rolniczych, a mianowicie Kurlandzkie Towarzystwo Ekonomiczne (Kurländische Ökonomische Gesellschaft) ${ }^{74}$.

W niektórych z izb mniejszości miały swoich przedstawicieli. I tak np. na 120 członków Izby Przemysłowo-Handlowej aż dziesięciu było Niemcami, sześciu Żydami i jeden Rosjaninem ${ }^{75}$. Z kolei w Izbie Reprezentantów Wolnych Zawodów na 150 członków było sześciu Niemców ${ }^{76}$.

Każda izba podlegała odpowiedniemu ministrowi, który wybierał jej członków na trzy lata, $\mathrm{z}$ tym że jedna trzecia składu była zmieniana co roku. Oczywiście te ciała posiadały tylko kompetencje doradcze. Całe dzieło zostało zwieńczone utworzeniem w 1939 r. Państwowej Rady Ekonomicznej (Valsts ekonomikas padome) i Państwowej Rady Kulturalnej (Valsts kulturas padome), których zamysłem powstania był rodzaj „zawodowego parlamentu”. Ich członkowie, w liczbie 68, brali udział w posiedzeniach rządu, o ile nie były utajnione, mieli prawo kierować interpelacje do ministrów i byli obecni podczas przyjęć korpusu dyplomatycznego. Największe mniejszości miały swoich pojedynczych reprezentantów i w tym ciele ${ }^{77}$.

Mimo ofensywnej polityki rządu Ulmanisa, zmierzającej szybkimi krokami do ujednolicenia życia społecznego, gospodarczego i kulturalnego Łotwy, mniejszości zachowały niektóre ze swoich organizacji, w tym najważniejsze, jak np. Wspólnotę Niemiecko-Bałtycką na Łotwie. Dzięki tej ostatniej mniejszość niemiecka mogła nadal prowadzić działalność kulturalną i społeczną. Z kolei Polacy mieli Towarzystwo Polaków na Łotwie, będące ogólnokrajową organizacją reprezentującą interesy mniejszości polskiej. Funkcjonowało też Polskie Towarzystwo Dobroczynne i Polskie Towarzystwo Oświaty ${ }^{78}$.

Niektóre mniejszości narodowe nie traciły nadziei na zmianę aktualnej polityki rządu łotewskiego lub przynajmniej częściowe ograniczenie jej negatywnych skutków. W pierwszym rzędzie odnosiło się to do przywódców Niemców bałtyckich. Jak ich poprzednicy przed pierwszą wojną światową, przywiązywali dużą wagę do osobistych kontaktów z czołowymi postaciami życia politycznego. W pełni zdawali sobie sprawę, że jakiekolwiek zmiany na Łotwie zależą od potężnego premiera, a od 1936 r. prezydenta w jednej osobie, Ulmanisa. Nic dziwnego, że zależało im na nawiązaniu kontaktów $z$ dyktatorem. Nie było to jednak łatwe zadanie. Wprawdzie Ulmanis zajmował wcześniej w kwestii mniejszości narodowych pozycję umiarkowaną i nie był źle nastawiony wobec Niemców bałtyckich, ale po 1934 r., w nowej sytuacji, twardo opowiadał się za konsekwentną realizacją hasła „Łotwa dla Łotyszy” i był znany z antyniemieckiej postawy. Początkowo Ulmanis

$74 \quad$ Ibidem, 159/3, Landamt der deutschbaltischen Volksgemeinschaft, Bericht über die Liquidation der deutschen landwirtschaftlichen Vereine in Lettland, 1-3.

75 Nation und Statt 5 (1938/39): 325.

76 Nation und Statt 4 (1938/39): 242.

77 Balodis, Latvijas, 248.

78 Ėriks Jekabsons, Poḷi Latvijā (Rīga: Latvijas ZA Filozofijas un Siciolog ijas instituts, 1997), 64. 
nie chciał nawet zgodzić się na przyjęcie przedstawicieli mniejszości niemieckiej. Po długich zabiegach przywództwa Wspólnoty Narodowej udało się doprowadzić do spotkań, jednakże aż do 1939 r. audiencje były zimne i nie przynosiły żadnego rezultatu, np. nie udało się przeforsować uzyskania pewnych koncesji w związku z wydaniem ustaw sylwestrowych. Podczas przyjęcia przywództwa mniejszości niemieckiej 31 stycznia 1936 r. Ulmanis odmówił jakichkolwiek obietnic złagodzenia możliwych skutków tych ustaw, nie mówiąc już o najmniejszych choćby zmianach $\mathrm{w}$ ich treści ${ }^{79}$. Także następne audiencje były bezowocne i upływały wśród wzajemnych pretensji i oskarżeń. Prezydent kładł nacisk na fakt, że Niemcy bałtyccy nadal byli odrębnym elementem w państwie łotewskim i nie chcieli współpracować z nową Łotwą. Szczególnie krytyczny stosunek miał do młodzieży niemieckiej. W związku z tym Ulmanis powtarzał, że Niemcy nie mają prawa skarżyć się na bezrobocie panujące wśród ich młodej generacji czy na to, że nie mogą nabywać ziemi. Niektóre z jego uwag były nawet obraźliwe dla Niemców, np. 18 grudnia 1937 r. miał powiedzieć Erichowi Mündelowi, przewodniczącemu Niemiecko-Bałtyckiej Wspólnoty Narodowej, że nie przywiązuje żadnego znaczenia do ludzi, którzy piszą swoje nazwiska tylko po niemiecku ${ }^{80}$ (od listopada 1937 r. urzędnikom zabroniono wpisywania w nawiasach niemieckiej formy nazwisk w dowodach osobistych i innych aktach urzędowych, czego zresztą nie chcieli często czynić i wcześniej) ${ }^{81}$.

Wraz z szybkim zaostrzaniem się sytuacji międzynarodowej Ulmanis zaczął jednak stwarzać przynajmniej pozory złagodzenia swojej polityki mniejszościowej i okazywać pewne względy Niemcom bałtyckim. Po raz pierwszy na audiencji noworocznej, w 1939 r., przyjął osobno przewodniczącego i wiceprzewodniczącego Niemieckiej Wspólnoty Narodowej i odbył z nimi długą rozmowę. Na zaproszenie niemieckiej Kościelnej Rady Ewangelickiej, 31 marca prezydent był obecny na wykonaniu Pasji według św. Mateusza Jana Sebastiana Bacha w Petrikirche ${ }^{82}$. Były to jednak tylko pozory. Ulmanis stanowczo odrzucił projekt zasadniczych zmian w polityce rządu wobec mniejszości niemieckiej, przedstawiony mu w kwietniu 1939 r. Przy okazji Ulmanis podkreślił, że mniejszość niemiecka powinna dążyć do stopienia się z narodem łotewskim, a nie ciągle tworzyć odrębny element ${ }^{83}$. Bez wątpienia słowa te najlepiej świadczą o głównym celu polityki rządu łotewskiego

79 Hans Ulrich Scupin, Die neuen lettländischen Wirtschaftsgesetze in ihrer Auswirkung auf die deutsche Volksgruppe in Lettland (Hamburg: Hanseatische Verl.-Anst, 1935), 49.

80 PAAA, Akten der deutsche Gesellschaft in Riga, 151/1, Deutsches Volkstum in Lettland, A-10,14 I 1938, Inhalt: Unterredung des Präsidenten der Deutschbaltischen Volksgemeinschaft mit den Staatspräsidenten, Aufzeichnung des Herren Gesandten über seine Unterhaltung mit dem Staatspräsidenten Ulmanis am 24. November 1938, s. 1-2; A-407, 19 III 1938, Inhalt: Empfangdes Präsidenten der Deutschbaltischen Volksgemeinschaft durch den Stattspräsidenten, s. 1.

81 Wolff, Die Rechtsbrücke, 112.

82 Jürgen von Hehn, „Ein Autonomieplan der deutschen Volksgruppe in Lettland um die Jahreswende 1938/39", w Reval und die baltischen Länder (Marburg: J.G. Herder Institut, 1981), 179-180.

83 J.G. Herder-Institut, Archiv, Marburg, A. Intelmann, Auszüge, 5-10. 
po przewrocie 15 maja 1934 r. wobec nie tylko niemieckiej, ale w ogóle wszystkich mniejszości narodowych.

W przeciwieństwie do Niemców bałtyckich, Rosjanie, bądź co bądź największa mniejszość, zachowali zupełną bierność w obliczu nowej polityki władz łotewskich. Nie protestując w ogóle, Rosjanie pogodzili się z ograniczeniem praw autonomii szkolnej, zmniejszeniem liczby ich towarzystw i wydawnictw prasowych. Te organizacje, które mogły nadal funkcjonować, nie próbowały przejawiać jakiejkolwiek, choćby najmniejszej, inicjatywy, co dziwiło nawet urzędników łotewskich ${ }^{84}$.

Jeżeli chodzi o mniejszość polską, to nie można powiedzieć, aby była negatywnie wyszczególniona spośród innych grup narodowych. Rządowi Ulmanisa zależało przede wszystkim na łotyszyzacji Łatgalii, a nie na denacjonalizacji Polaków jako takich. Można właściwie stwierdzić, że najbardziej antypolską politykę prowadzono wcześniej, za rządów Skujenieksa, kiedy to został zawieszony Związek Polaków na Łotwie. Po 15 maja 1934 r. sytuacja nawet się pod pewnymi względami poprawiła. Ulmanis zezwolił już w 1934 r. na reaktywowanie działalności rzeczonego związku ${ }^{85}$.

Nie licząc poważnych ograniczeń w życiu gospodarczym, które odnosiły się do wszystkich mniejszości, a nie akurat Żydów, polityka narodowościowa Ulmanisa nie wyróżniała też negatywnie Żydów. Wręcz przeciwnie, dyktator demonstrował wprost swój pozytywny stosunek do ludności żydowskiej. O urzędowym czy choćby półoficjalnym antysemityzmie nie mogło być w ogóle mowy. Łotwa była jedynym krajem w Europie, pomijając ZSRR, który zakazał publiczne szerzenie antysemityzmu. Na Łotwie, w całym zresztą okresie międzywojennym, nie miał miejsca ani jeden pogrom ludności żydowskiej. Nie wprowadzono ani jednego prawa skierowanego przeciw Żydom. Ulmanis osobiście wyraził zgodę na przyjęcie wyjeżdżających z III Rzeszy Żydów, w czasie gdy inne kraje, w tym najbardziej filosemickie, jak USA, tego uczynić nie chciały ${ }^{86}$.

Stosunkowo życzliwie reżym Ulmanisa traktował mniejszość litewską i estońską ${ }^{87}$. Niewątpliwie było to związane $z$ faktem, iż reprezentowały one pozostałe „bratnie” kraje bałtyckie, choć trzeba pamiętać, że relacje Rygi z Tallinem i Kownem nie zawsze układały się dobrze i wzajemnych niesnasek nie brakowało. Zresztą były to bardzo małe mniejszości: Litwini stanowili 1,17\% (22 913) ogółu mieszkańców, a Estończycy zaledwie 0,36\% (7014) ${ }^{88}$.

Za rządów autorytarnych Ulmanisa była jedna mniejszość, która była nawet faworyzowana i której świadomość narodową starano się podnieść. Chodzi o najmniejszą grupę narodową, mianowicie Liwów, zamieszkałych od najdawniejszych czasów na wybrzeżu Bałtyku, głównie w okolicach Windawy. Według spisu z 1935 r.

${ }^{84}$ Istorija Latviji, 205.

85 Więcej o Polakach na Łotwie: Janusz Albin, Polski ruch narodowy na Łotwie 1919-1940 (Wrocław: Wydawnictwo Uniwersytetu Wrocławskiego, 1993).

${ }^{86}$ Istorija Latviji, 210.

87 Kolendo, Łotwa, 170.

${ }^{88}$ Latvijas skaitlos, 39. 
do narodowości liwskiej przyznawało się 898 osób, z czego tylko 514 znało język rodzimy, wywodzący się z grupy ugrofińskiej. Nie stawiano żadnych przeszkód w działalności ich głównej organizacji społeczno-kulturalnej, Wspólnoty Liwskiej, a Ulmanis wziął nawet udział w obchodach głównego liwskiego święta - Święta Morza - w Mazirbe (Irē), 9 lipca 1936 r. Władze patronowały też budowie Liwskiego Domu Narodowego (Libiestu Tautas Nams). Łotewski Fundusz Kulturalny, na którego czele stał właśnie Ulmanis, przeznaczył na ten cel kilkanaście tysięcy łatów. Fundusze zbierano na Łotwie, ale także w Finlandii, Estonii, Litwie i na Węgrzech. Budynek uroczyście oddano do użytku 9 maja 1939 r. Gdy rynek wydawniczy i prasowy mniejszości narodowych się kurczył, właśnie w drugiej połowie lat trzydziestych zaczęly się ukazywać pierwsze, w ogóle, książki w języku liwskim, a od 1936 r. wychodził pierwszy miesięcznik, „Livli”»9. Śmiało więc można powiedzieć, że reżym Ulmanisa dokładał starań, aby zanikająca powoli mniejszość narodowa całkowicie nie zaginęła w łotewskim morzu i aby utrzymała, a nawet wzmocniła, swoją narodową tożsamość.

Jesienią 1939 r. Łotwa pozbyła się tej mniejszości, która uważała za najgroźniejszą, mianowicie Niemców bałtyckich. Wynikało to jednak nie z polityki rządu łotewskiego, a z inicjatywy III Rzeszy, która wyraziła wówczas chęć przesiedlenia mniejszości niemieckiej z kilku krajów europejskich, w tym Łotwy i Estonii. Nie trzeba dodawać, że władze łotewskie skwapliwie się na to zgodziły. Wyjeżdżających Niemców nie żegnano z żalem. Na wspólnym posiedzeniu Izby Gospodarczej i Kulturalnej Ulmanis powiedział, przy nieustającym aplauzie, „do nie zobaczenia” (uz nieatgriešanos $)^{90}$. Po opuszczeniu Łotwy przez zdecydowaną większość Niemców bałtyckich władze tego kraju gorliwie zabrały się do wymazywania wszelkich śladów niemczyzny. Na początku 1940 r. wyszło rozporządzenie nakazujące zmianę wszystkich nazwisk pochodzenia niemieckiego na łotewsko brzmiące. Doszło do tego, że usuwano nawet napisy niemieckie z grobów. Podobny los spotkał też napisy niemieckie pod obrazami w kościołach ${ }^{91}$.

Polityki narodowościowej Łotwy za czasów dyktatury Ulmanisa nie można ocenić jednoznacznie. Niewątpliwie na tle pozostałych krajów bałtyckich była ona najbardziej restrykcyjna. Jednakże, uwzględniając ówczesne realia europejskie, Łotwa nie wypada negatywnie. Dążono raczej do wzmocnienia pozycji Łotyszów i nadania Łotwie bardziej łotewskiego charakteru, do wzmocnienia państwa niż do denacjonalizacji mniejszości jako takich. Polityka władz łotewskich nie miała też żadnych odcieni rasistowskich. Za głównego przeciwnika uważano mniejszość niemiecką, jako najsilniejszą kulturalnie i gospodarczo. Należy jednak pamiętać, że od samego początku łotewskiego przebudzenia narodowego za głównego wroga

89 Libieši: vēsture, valoda un kultura (Rīga, 2013), 421.

90 Jānis Stradinš, „Die Deutsche in der Kulturgeschichte Lettlands unter besonderen Berücksichtigung der Wissenschaftsgeschichte", Nord-Ost Archiv, Neue Folge 1 (1992): 126.

${ }_{91}$ Bundesarchiv, Berlin-Lic hterfelde, R 57, 1081, 14 II 1940, Ausmerzung der Deutsceh in Lettland. 
uchodzili właśnie Niemcy, a nastroje antyniemieckie utrzymywały się do końca okresu międzywojennego w całym społeczeństwie łotewskim, niezależnie od orientacji politycznej.

\section{Andrzej Topij \\ Latvia's Nationalities Policy under the Authoritarian Regime of Kārlis Ulmanis}

(1934-1940)

\section{Summary}

In the 1930s, as many as eight nationalities (besides Latvians) lived in Latvia. These were Russians, Jews, Germans, Poles, Estonians, Lithuanians, Belarusians, and Livonians. These minorities constituted 26.5 percent of the entire population of the state, and maintained (although to a varying degree) a strong position in the economic and intellectual life of Latvia. Germans and Jews, above all, played an important role in the economic life of the country. Latvians, however, enjoyed a favorable position in agriculture because of the agricultural reforms introduced after the First World War, which liquidated large Germanand Polish-owned estates.

Latvian policy toward the national minorities changed after 15 May 1934, that is after the coup d'état instigated by Kārlis Ulmanis, who established an authoritarian system of government. Ulmanis implemented nationalist policies aimed at national minorities, although this was not a policy of repression and ethnic oppression. 